\title{
Impacts of Corona Virus Disease-19 on Dairy Farming and Its Marketing System
}

\author{
Bayesa Tolasa \\ Werabe University, College of Agriculture and Natural Resource, Department of Animal Science, P.O.Box: 46. \\ Werabe, Ethiopia
}

\begin{abstract}
The corona virus disease-19(COVID-19) epidemic expanded in early December, 2019 from Wuhan, China has been represents an unprecedented emergency. Since the disease declared as pandemic worldwide, a lot of its impacts have been appeared on economy. Dairy is a key contributor to the world food supply, especially for the world's most vulnerable populations. However, the effects of Corona virus disease-19 (COVID-19) on this sector are still largely unquantified. By considering this the present paper is aimed to review the impacts of corona virus disease-19 (COVID-19) on dairy production and its marketing system. After Corona Virus Disease-19 (COVID19 had been come, the factors such as lockdown, travel restrictions and border control have been consequences in difficulty to moving live animals and animal products like dairy and dairy products to markets, restricted capacity to purchase necessary production inputs, labour and professional services. Generally, an epidemic indicates the disruptions on growth, along with socio-economic consequences such as: reduced access to feed, processing, marketing, and transportation. Therefore, special aid and permits needed to transport animal feed, keep inputs flowing and empower producer.
\end{abstract}

Keywords: Corona Virus; Dairy; Products; Marketing; Impact

DOI: $10.7176 / \mathrm{JAAS} / 69-01$

Publication date:October $31^{\text {st }} 2020$

\section{INTRODUCTION}

Coronaviruses are a large family of viruses found in both animals and humans which belong to the family of Coronaviridae [1]. The virus has a natural and zoonotic origin in which two scenarios that can plausibly explain the origin of severe acute respiratory syndrome (SARS-CoV2) that means that natural selection can be takes place in an animal host before zoonotic transfer in then in humans [2,3]. Its major clinical features and risk factors are highly variable by making the clinical severity range from asymptomatic to fatal [4]. The most common symptoms are fever, cough, fatigue, sputum production, headache, haemoptysis, diarrhoea, dyspnoea, and lymphopenia [1].

It is not the first time that a coronavirus causing an epidemic has been a significant global health threat since in November 2019, an outbreak of coronaviruses (CoVs) with severe acute respiratory syndrome (SARS)-CoV started in the Chinese province of Guangdong and again as well as in September 2012, the Middle East respiratory syndrome (MERS)-CoV have been appeared $[3,5,6]$. At the end of 2019, a series of pneumonia cases of unknown cause emerged in Wuhan (Hubei, China) [2,5]. Consequently, on February 11th, 2020, the World Health Organization (WHO) Director-General, Dr. Tedros Adhanom Ghebreyesus, named the disease caused by the SARS-CoV-2 as "Corona Virus Disease"(COVID-19) and by March 11th, 2020 when the number of countries involved were 114,with more than 118,000 cases and over 4000 deaths, the WHO declared the pandemic status [1].

Historically, severe acute respiratory syndrome corona virus -2 (SARS-CoV-2) is zoonotic in that means it affects humans and some animals [7,8]. So that, domestic animals living closely live with COVID-19 positive human cases can be exposed to the virus, either through environmental contamination or through human-animal interaction $[9,10]$. For instance, some cat sera collected after the outbreak in Wuhan city, Hubei Province, were positive for while neutralizing antibodies [10]. Similarly, potential reverse zoonotic transmission has been seen in other settings such as tigers in Bronx Zoo [9]. After this viral disease is declared as pandemic worldwide, dairy production and its marketing system have been affected due to restriction of movements, physical distancing and closure of markets and trade [7]. However, dairy and dairy products are a key contributor to world food supply, especially for the world's most vulnerable populations [1,9].

Moreover, dairy and dairy products are the highly important and recommended protein supply for human food needs particularly for babies and elders [9]. Fortunately, since COVID-19 may attack immune system therefore milk consumption is very important to build defensive immune system [1]. By considering this, the present paper aimed to review the impacts of corona virus disease-19 (COVID-19) on the dairy production and its marketing system which could be compiled information on the enhancement and continuity of dairy production and marketing system for sustainable milk consumption.

IMPACTS OF CORONA VIRUS DISEASE-19 ON DAIRY FARMING AND ITS MARKETING SYSTEM Due to the physical distancing, the requirements for additional equipment which are used for personal protective 
reducing the efficiency of industrial feed enterprises [5,9,11]. And also, movement restrictions which are resulting in labour shortages could be reduced supply of raw materials or other ingredients [1]. Consequently, dairy farmers are forced to dump dairy and dairy product after remarkable decrease in supply of it and closure of milk processing company. For instance, Farmers in Winconsin, United States of America, were compelled to dump 25000 gallons of fresh milk a day because there was no chance to transport it [12].

On the other hand, movement restriction and disruption of national and international trade routes are curbing farmer access to breeding materials and replacement stocks [11]. It can compromise sales for input providers [10]. The disruption of food safety inspection and animal health extension services, combined with interrupted delivery and use of vaccines and medicines is increasing the likelihood of new epidemics, including those involving animal diseases that cause major livestock losses. For instance, African swine fever in East and Southeast Asia and outbreaks of diseases transmissible to humans [9]. Moreover, import restrictions may have impact on areas that depend on imports to sustain production or rely on dairy and dairy products imports for consumption. For instance, large part of Africa and Small Island developing states [7].

Farmers are having to keep their stock longer or dump milk, leaving them with higher production costs or important losses due to the result of limited access to markets and slaughter houses/processing plants [7,12]. Additionally, closure of live animal markets in many countries means small-scale producers cannot sell their goods why because the disruption of the logistical channel and drop in demand are reducing sales and lowering prices [7,9]. Disruptions of income from dairy are hitting women hardest by reducing their purchases of household essentials and nutrition [7]. Moreover, on-going conflicts in Iraq, Libya, the Syrian Arab Republic, and Yemen and economic hardships in Lebanon and Sudan are exacerbating matters [1]. Restrictions of movement are also interrupting the role of intermediaries, who collect animals or products and aggregate them for further dairying, processing, or retailing [7,9]. Furthermore, in West Africa, many live animals from markets are closed while pastoralists are compelled to destock massively [7]. From previous epidemic experiences, these disruptions of intermediaries can cause farmers to lose their linkage to larger buyers, especially information systems linking value chain actors.

In country like France, staff shortages have faced due to childcare, quarantine, and sick leave have reached 30 percent in some slaughter houses and staff reductions due to restrictions measures are constraining dairy processing industries, given their labour-intensive nature [9]. In another country like Egypt, Jordan and Tunisia there are similar instances of staff shortages have faced in dairy processing industries [7]. On the other hand, trucking companies that haul dairy products are struggling to get enough drivers as some have stopped working due to fear of contagion [13].

However, much of milk processing in developing countries are informal even before corona virus disease-19 (COVID-19) prevention and response disrupts these businesses [1,7,9]. This disruption removes an outlet for small-scale producers, who often lack the capacity to sell to formal markets [9]. On other side, disruptions of transport and changes in retailing and consumption habits are compelling some collectors and processors to stop stock of dairy and dairy products [7].

In most country, restrictions of movement are compromising transport, which is reducing the supply of dairy and dairy products [1]. In China, milk processing and transport were disrupted by tight road traffic control, compelling to milk dumping [11,14]. Similarly, delays of vehicles transporting raw materials for processing milk threatened to cause a shortage until movement bans were loosened in Philippines [1]. In line to this, restrictions of trade affect the countries exporting dairy and dairy products as well as farmers whose incomes depend on exports [4]. In Poland a recent ban on exports caused farm gate prices to fall, as domestic consumption only represents 15 percent of production [1,7]. Beside to this, transport was disrupted by tight road traffic control in China [10]. Moreover, restrictions of movement have also stopped dairy trade to China from the Lao People's Democratic Republic, Myanmar, Thailand and Viet Nam [9]. Above all, dairy producers, traders, and butchers lost their incomes because they could not export their animals and dairy [7]. Furthermore, milk export drops in Latin America, especially in Argentina and Uruguay, have also reduced farmer revenues [9,10]. Disruptions to live animal transport can also have serious consequences on the availability of products in the importing country [7].

One way of reorienting toward supermarkets and online platforms is retailing, which are now spiking [7]. In China, leading e-commerce food delivery platforms increased their volumes by 400 percent in February 2020, while their precrisis share of fresh food consumption was only 3 percent. This means more packaged, longer-life, and processed milk being shipped. While some farmers in Europe and North America seem to be able to create alternative and direct channels with consumers, in countries with a low penetration of e-commerce, processing industries or supermarkets, farmers cannot sell their produce [7]. In Viet Nam, informal markets and food vendors are under higher scrutiny, and supermarkets are selling more processed dairy and dairy products [7,9]. The United Arab Emirates has closed all dairy and dairy products market, but it has kept supermarkets open 24 hours a day at 30 percent maximum visitor capacity $[1,9,10]$.

The most constraining purchasing power is lockdowns particularly that of informal workers and in countries with little or no social safety nets [1]. The economic slowdown and increasing unemployment have already left 
people, including millions of migrant workers in India, with little or no income with which to buy food $[1,7,9]$. During the 2014 Ebola crisis in West Africa, the decrease in purchasing power reduced domestic animal production. However, in the current crisis, informal markets are being closed or constrained across Africa [7].

In China's Hubei province, authorities reported an 80 percent decrease in transaction receipts for all sectors in February 2020 compared to 2019. However, at the end of March 2020 when measures were lifted, overall consumption rose back to 93 percent of its 2019 level [10]. Moreover, fake news and rumours can also affect demand.

\section{CONCLUSION}

The corona virus disease-19(COVID-19) epidemic expanded in early December from Wuhan, China. By following the pandemic, a lot of impacts are appeared on agricultural sector especially on dairy sub-sector. Among the factors, physical distancing and requirements for additional personal protective equipment are reducing the efficiency of industrial feed enterprises that could be resulted in reduced access to feed. Similarly, closure of live animal markets in many countries means small-scale producers cannot sell their goods. Moreover, staff reductions due to lockdown measures are constraining dairy processing industries, given their labour-intensive nature. Generally, an epidemic indicates the disruptions on growth, along with socio-economic consequences such as: reduced access to feed, processing, marketing, and transportation. Therefore, special aid and permits needed to transport animal feed, keep inputs flowing and empower producer.

\section{REFERANCES}

[1] World Health Organization, 2020. Director-General's Opening Remarks at the Media Briefing on COVID-19 on -11 March 2020. Available online: https://www.who.int/dg/speeches/detail/who-director-general-s-

[2] Huang, C.; Wang, Y.; Li, Z.; Ren, L.; Zhao, J.; Hu, Y.; Zhang, L.; Fan, G.; Xu, J.; Gu, X, 2020. Clinical features of patients infected with 2019 novel coronavirus in Wuhan, China. Lancet 2020, 395, 497-506.

[3] R. Lu,X. Zhao, J. Li, P. Niu, B. Yang, H. Wu, W. Wang, H. Song, B. Huang, N. Zhu, 2020. Genomic characterisation and epidemiology of 2019 novel coronavirus: Implications for virus origins and receptor binding. Lancet 2020, 395, 565-574.

[4] T. Phan, 2020. Novel coronavirus: From discovery to clinical diagnostics. Infect. Genet”. Evol. $2020,79$.

[5] Centers for Disease Control and Prevention, 2020. The 2019 Novel Corona virus, Wuhan, China. Available online: https:/www.cdc.gov/coronavirus/2019-ncov/prevent-getting-sick/prevention. Html (accessed on13, April 2020).

[6] S. Perlman, J. Netland, 2009. Coronaviruses post-SARS: Update on replication and pathogenesis". Nat. Rev. Microbiol. 2009, 7, 439-450.

[7] Food and Agriculture Organization (FAO), 2020. COVID-19 pandemic - impact on food and agriculture. In: Novel Coronavirus (COVID19).http://www.fao.org/2019-ncov/q-and-a/impact-on-food.

[8] A. M. O’Connor, S. C. Totton, \& J.M. Sargeant, 2020. A rapid review of evidence of infection of pets and livestock with human-associated coronavirus diseases, SARS, MERS, and COVID-19, and evidence of the fomite potential of pets and livestock. In: Systematic Reviews for Animals \& Food (SYREAF) [online]. [Cited 30 April 2020]. http://www.syreaf.org/wp-content/uploads/2020/04/Rapid-Review-of-pets-asfomites_3.pdf.

[9] World Organisation for Animal Health (OIE), 2020. COVID-19 (SARS-COV-2), Hong Kong (SAR - PRC), $\begin{array}{lllllll}\text { Follow-up report } & \text { No. } 2 . & \text { [Online]. } & \text { Paris. } & \text { [Cited } & 30 & \text { April }\end{array}$ 2020].https://www.oie.int/wahis_2/public/wahid.php/Reviewreport/Review?page_refer=Map Full Event Report \& reported $=33629$.

[10] Q. Zhang, H. Zhang, K. Huang Y. Yang, X. Hui, J. Gao, X. He, C. Li, W. Gong, Y. Zhang, C. Peng, X. Gao, H. Chen, Z. Zou, Z. Shi and M. Jin, $2020 . \quad$ SARSCoV neutralizing serum antibodies in cats: a serological investigation". Bio Rxiv, 1 April 2020 [online]. [Cit ed30April2020].https:/www.biorxiv.org/content/10.1101/2020.04.01.021196v1.full.pdf.

[11] Chinese Association of Rehabilitation Medicine (CARM), 2020. Respiratory rehabilitation committee of Chinese Association of Rehabilitation Medicine. Cardiopulmonary rehabilitation group of Chinese society of physical medicine and rehabilitation”. Zhong Hua Jie He He Hu Xi Za Zhi 2020, 43, E029.

[12] R. Barrett, 2020. Wisconsin farmers forced to dump milk as coronavirus slams a fragile dairy economy. $\begin{array}{llllll}\text { Milwaukee } & \text { Journal } & \text { Sentinel, } & 2 & \text { April } & 2020 .\end{array}$ [online]. https://eu.jsonline.com/story/money/2020/04/01/coronavirus-forces-dairy-farmers-dump-milkwisconsincovid-19/5108609002/.

[13] P. J. Huffstutter, 2020. U.S. dairy farmers dump milk as pandemic upends in food markets". World Economic Forum, 7 April 2020. [online]. https://www.weforum.org/agenda/2020/04/dairy-milk-pandemicsupplychains-coronavirus-covid19-pandemic/.

[14] X. Zhang, 2020. Chinese livestock farms struggle under COVID-19 restrictions". IFORI Blog : Research Post, 26 March 2020. [online]. https://www.ifpri.org/blog/chinese. 